\title{
Incorporation of Smartphones and Social Media to Promote Mobile Learning in an Indonesian Vocational Higher Education Setting
}

\author{
https://doi.org/10.3991/ijim.v14i19.13863 \\ Purnomo Ananto $(\bowtie)$ \\ State Polytechnic of Kreatif Media, Jakarta, Indonesia \\ purnomo.anantolpolimedia.ac.id \\ Sri Kusuma Ningsih \\ University of Muhammadiyah Prof. Dr. Hamka, Jakarta, Indonesia
}

\begin{abstract}
This brief article reports on an exploration of students' adoption of smartphone technology and social media to promote m-learning in the context of a state polytechnic classroom. To this end, a mixed-methods approach was employed. A quantitative survey involved 221 students across education programmes in an Indonesian vocational higher education, and six of them were asked to write a reflection after a course. Findings of the current study have revealed that students' attitude and connectedness to the smartphone and social media play prominent roles in determining their acceptance of smartphones and social media for m-learning. Specifically, the students' connectedness, perceived ease of use and perceived playfulness of using social media for mlearning affected their attitude. Findings of the study also revealed that students' mobile learning using the smartphone helped develop their learning motivation, facilitated learning activities and enabled interaction amongst the students, and between teachers and students. Students also benefited from the use of the smartphone by which means they could share information and materials about the learning, enabled peer-assessment and feedback. Two critical issues that were found included limited smartphone features and less space for interaction and explanation.
\end{abstract}

Keywords-Smartphone, mobile learning, polytechnic, learning motivation, interaction, learning performance

\section{Introduction}

The advancement of mobile technologies has promoted the shift of online learning application and practices from the use of personal computers to portable devices such as pocket PCs, tablet computers and smartphones [1]. Mobile learning (henceforth $\mathrm{m}$ learning) is a term commonly used to present a connection of e-learning and mobile computing, providing students with opportunities to experience learning in both formal and informal educational settings [2]. Digital devices that students can use to 
access m-learning include smartphones, laptops, iPods, personal digital assistants and other devices [1], [3]-[5]. Papadakis, Vaiopoulou, Kalogiannakis, and Stamovlasis [6] have argued the values of several digital devices in addressing the limitation of the 'traditional' graphic user interface from PCs or laptops computers. Papadakis et al also assert that the incorporation of the digital devices may provide an opportunity for students to personlise their learning experiences and improve students' engagement as well. Besides, Gikas and Grant [7] suggest the benefits of mobile computing devices for m-learning, including that they provide more educational opportunities for students in remote areas to access course content and to interact with teachers and other students. Some authors also believe that the incorporation of mobile computing devices in conjunction with social media will create more access for interaction and communication which will, thus, enhance learning [7], [8].

The incorporation of the smartphone and social media to enhance learning in the higher education context is evidenced in the literature [1], [4], [7], [8]. Social media is used not only to facilitate interaction and communication but also to provide more accessible learning resources, to promote collaborative learning [9]-[11] and to create an authentic learning environment [4], [12]. Sobaih, Moustafa, Ghandforoush and Khan [13] suggest that social media can be an alternative online learning solution for developing countries who often lack an infrastructure, communication technology and other advanced online learning management systems.

The current study aims to explore the adoption of smartphone technology in students' m-learning during their courses in a state polytechnic classroom. Particularly, it addresses two questions as below:

1. What are students' technological acceptance and connectedness to learning to the use of social media to promote m-learning?

2. To what extent does m-learning with the smartphone and social media facilitate students' learning motivation, interaction and learning performance?

\section{Literature Review}

\subsection{Mobile learning in a higher education setting}

Mobile learning has been widely practised in higher education across the world. For instance, a survey by Dahlstrom [14] suggested that students are currently leading the implementation of mobile technological devices into their classrooms. Moreover, $67 \%$ of the surveyed students expressed the view that mobile technology is undoubtedly crucial to their academic activities and outcomes. Moreover, advanced mobile technology has enabled the integration of a learning management system into many mobile operating systems [15]. Literature has also suggested that m-learning could reduce the gap between formal and informal learning environment allowing students to access learning resources with their preferences anytime and anywhere [16]-[18]. Pedro et al. [17] argue that the incorporation of m-learning in and outside the classroom promotes immediacy, mobility and convenience in learning. 
There is a body of literature that suggests that the incorporation of m-learning in education enables students to have a better awareness of team collaboration, creative thinking, critical thinking, problem-solving and communication [16], [19]. A study by Chang et al. [19] found that students had better self-awareness in team collaboration and creative thinking, although there was no significant difference between male and female students. The finding of the study also revealed that students who study in educational institutions where m-learning was used in more extended periods tend to have higher awareness than those where m-learning is used less.

M-learning has also been widely incorporated in vocational higher education classrooms. In an accounting classroom, Seow and Wong [20] developed a mobile game application called Accounting Challenge (ACE) to facilitate learning accounting. In particular, the application is aimed to encourage students to learn about accounting in an entertaining way outside the classroom. They found that ACE promoted flexible learning, and applications make learning accounting more enjoyable. In a study, Li, Lee, Wong, Yau, and Wong [21] examined the effect of using mobile apps to promote the motivation, social interaction and learning performance of 20 nursing students. The findings revealed that students had a high level of motivation in learning and accomplishments. However, a few students were observed to be less satisfied and had insufficient self-efficacy with the m-learning. From the comparison of two tests, the study found students performed better after practicing m-learning. Cheung [22] explored the use of the smartphone and attitudes towards its use for m-learning in marketing and public relation subjects. He found that students' $\mathrm{m}$-learning intentions were mainly affected by students' aspects (e.g. students' willingness and attitude towards smartphone for learning, students' technological competence to address academic matters), online interactions, features offered in the device, and sharing facilities.

Despite the plethora of m-learning in vocational higher education, some critical issues were found concerning its incorporation in teaching and learning practices, such as concerns about the readiness of college campuses to adopt m-learning [23], technological competence [24] and physical and social spaces for a learning environment [16]. The other challenges are technical, including low processing power and speed of the mobile devices, the small screen size that affects visibility and readability of the texts, limited storage, and short battery life [2].

\subsection{Incorporating social media to support students' online learning in a higher education setting}

Statistics have shown that the number of people accessing social media grows every year. In the Indonesian context, Mulyono and Gunawan [4] present data that reports about $95 \%$ of Indonesian internet users were users of social media in 2013 and the percentage had grown to $97.9 \%$ by 2018 . Such growth also affects the number of teachers and students at university [9]. Literature has suggested that social media adoption has effects on students' learning. For example, social media provides more accessible information for students about learning activities [9]. The adoption of social media for teaching and learning also enables the teachers and students to share learning materials at their ease [25]. Social media also offers more room for teachers' 
and students' interaction and communication and thus promotes engagement [26] and enables collaborative learning [9]-[11].

A body of literature has documented the incorporation of social media in the university classroom across Indonesian provinces. Susilo [27] examined the potential use of Facebook for an academic learning network in the context of the Indonesian open university. Salikin and Tahir [28] examined the use of social media to help improve students' writing of descriptive text. La Hansin, Risdiany, Utami and Sulisworo [29] investigated the incorporation of WhatsApp to facilitate collaborative writing in the English language learning classroom. Rehaded, Puspitasari, and Hidayati [30] investigated the effect of Whatsapp use on undergraduate students in a private university. Unfortunately, little has been explored regarding the adoption of smartphone and social media in the vocational higher education context. This study, therefore, aims to address this gap by evaluating vocational higher education students' technological acceptance and connectedness to the use of social media to promote m-learning; and the extent to which m-learning with smartphones and social media facilitate students' learning motivation, interaction and learning performance. The current study contributes to the current literature of the unified theory of technology acceptance and use of technology (UTAUT) and connected learning contextualized in Indonesian vocational higher education. More importantly, the study will demonstrate the potential use of mixed method approach in examining students' acceptance of smartphone for learning and their connectedness in the learning itself.

\section{Methodology}

\subsection{Study design}

A mixed-methods approach was adopted to conduct the current study. Creswell [31] argues that mixed-methods provide an opportunity for researchers to collect both quantitative and qualitative data to allow them to address the research questions. In the current study, the quantitative approach design was aimed to address Research Question 1, examining students' technological acceptance and connectedness to the use of social media to promote m-learning. A survey method was adopted in the quantitative design. According to Cohen, Manion, Morrison and Bell [32], survey provides an opportunity for researchers to collect quantitative data with time efficient. Moreover, they also argue that survey enables the researchers to target abundant number of study participants and generate quantitative data at their ease. In the current study, a research questionnaire was administered to a total of 221 students across education programs in the polytechnic which 174 of whom completed it (see section 3.2.).

The qualitative research design was employed to address Research Question 2, evaluating the extent to which m-learning by smartphone facilitates students' learning motivation, interaction and learning performance. Student written reflection method was employed in the qualitative research design to capture students' views on the incorporation of smartphone to support their learning inside and outside the class- 
room. Zacharias [42] argues the students' reflection can be used as a tool to explore the student participants' voices in the classroom, allowing researchers to recognise the discrepancy between what teachers expect from the students and what students have learned. To this end, the reflection-on-action (RoA) method was adopted in which six students were asked to write a reflection on what they had experienced during the incorporation of smartphone to support the learning activities.

\subsection{Setting and the participants}

The current study was conducted in the state polytechnic of Kreatif Media in Jakarta, Indonesia. The polytechnic was established in 2008 to sustain the Indonesian creative and cultural industry. It offers some education programs with several concentrations including design, publishing, broadcasting, graphic design, game technology, packaging technology, and animation. There were twelve study programs with lengths of study ranging from a one-year to a four-year diploma.

Using a non-probability sampling technique, a total of 221 students across education programs in the polytechnic participated in the current study where they were asked to complete a technological acceptance questionnaire. A total of 221 students completed the questionnaire, but only 174 students mentioned that they used a smartphone and social media for m-learning (see Table 1). These 174 records were then used for further structural equation modelling (SEM) in the quantitative data analysis with SmartPLS software [33]. Six out of 174 students were then randomly invited to participate in an interview session.

\subsection{Method for data collection and analysis}

The data of the current study were gathered through surveys and students' writing reflection on their use of smartphones for m-learning during a course. An online survey questionnaire was developed to collect quantitative data from the students. The online development of the survey instrument was aimed at easing the distribution of the instrument, target wider participation and promote automatic data collection as well as tabulation [34], [35]. The questionnaire included three main sections: demographic information, the unified theory of acceptance and use of technology (UTAUT) section and connected learning environment. The demographic information included gender and age. The UTAUT questionnaire section was adapted from some previous studies [36]-[39]. The section comprised 26 items with six constructs: Perceived usefulness or PU (4 items), perceived ease of use or PE (4 items), subjective norm or SN (3 items), perceived playfulness or PP (3 items), attitude or ATT (4 items) and acceptance or ACC (3 items). The connected learning section was adapted from Dwyer, Bingham, Carlson, Prisbell, Cruz, and Fus's [40] connected classroom climate (CCC) inventory comprising a single aspect with four items. All items in the survey questionnaire were measured on a five-point Likert scale ranging from strongly agree (scored 5) to strongly disagree (scored 1).

After a one-month distribution period, the online questionnaire was halted with a total of 221 records. A spreadsheet was created from the Google form to allow the 
researcher to perform data tabulation and screening [34]. The spreadsheet was then downloaded and converted into an Excel file. The data were scored and tabulated. Out of 221 , only 174 students mentioned that they used a smartphone and social media for m-learning (see Table 1). These 174 records were then used for further structural equation modelling (SEM) in the quantitative data analysis.

In addition to the survey, the qualitative data were gathered using the students' written reflection. Six of the 174 participants were selected randomly to write a reflection. Coulson and Harvey [41] perceive reflection as an alternative to promote students' learning and help improve their higher-order thinking through the experience. Reflection can also be used as a tool for teachers to explore the learners' voices in the classroom, identifying the discrepancy between what teachers expect from the students and what students have learned [42]. In the higher education context, engaging in learning reflection is critical in students' learning as it allows teachers and students to recognize both the strengths and weaknesses of the teaching itself [43]. The reflection-on-action (RoA) method was adopted to encourage students' reflection. By such a method, students were encouraged to write a reflection on what they had experienced at the end of their course [44], [45]. Eight reflective questions were given to the students to help them systematically express their views [16]. Students' reflections were collected and analyzed qualitatively using Rayford's [46] procedure.

\section{$4 \quad$ Findings}

\subsection{Findings of the quantitative data analysis}

Table 1 shows the demography of the participants and Figure 1 presents the data related to students' use of social media to promote m-learning. As shown in Figure 1, findings of the descriptive analysis from the quantitative data shows that WhatsApp was the most popular social media used by the students to promote m-learning $(\mathrm{N}=163)$, followed by YouTube $(\mathrm{N}=117)$, Instagram $(\mathrm{N}=108)$, Twitter $(\mathrm{N}=55)$ and Facebook $(\mathrm{N}=29)$. The popularity of WhatsApp, YouTube and Instagram might be due to students' need to publish their works (e.g. movies, animation and images) on social media without having a reduction on the image or video quality.

Table 1. Demography of the participants

\begin{tabular}{|l|c|c|}
\hline \multicolumn{1}{|c|}{ Demography } & N & Pendercentage \\
\hline \multicolumn{3}{|c|}{} \\
\hline Male & 54 & 31.1 \\
Female & 120 & 68.9 \\
\hline \multicolumn{3}{|c|}{ Age } \\
\hline$<20$ & 100 & 57.5 \\
$20-25$ & 74 & 42.5 \\
$26-30$ & 0 & 0 \\
$30<$ & 0 & 0 \\
\hline
\end{tabular}

Table 2 below presents the descriptive statistics among the variables. 
Table 2. Mean and standard deviation for all variables

\begin{tabular}{|l|c|c|c|}
\hline \multicolumn{1}{|c|}{ Variables } & Number of items & M & SD \\
\hline Perceived usefulness (PU) & 4 & 3.53 & 0.77 \\
\hline Perceived ease of use (PE) & 4 & 3.19 & 0.79 \\
\hline Subjective norm (SN) & 3 & 3.54 & 0.66 \\
\hline Perceived playfulness (PP) & 3 & 3.48 & 0.76 \\
\hline Connected learning (CL) & 4 & 3.24 & 0.73 \\
\hline Attitude (ATT) & 4 & 3.03 & 0.76 \\
\hline Acceptance (ACC) & 3 & 3.00 & 0.84 \\
\hline
\end{tabular}

Table 2 above presents the mean and standard deviation of the research variables. The variables 'Subjective Norm' and 'Perceived usefulness' are shown to have the highest mean of 3.54 and 3.53 , with a standard deviation of 0.66 and 0.77 , respectively. In contrast, students' acceptance of and attitude towards social media for $\mathrm{m}$ learning are observed to be the lowest mean of, respectively, 3.00 and 3.03 with a standard deviation of 0.84 and 0.76 .

The instrument validity and reliability were examined by three primary indicators, including factor loadings, composite reliability coefficients, and the average variance extracted (AVE) [36], [37], [47]. All factor loadings were observed as higher than 0.70 .

Table 3. Reliability and validity analysis

\begin{tabular}{|l|c|c|c|c|c|c|c|c|c|c|}
\hline & \multicolumn{2}{|c|}{ Reliability } & \multirow{2}{*}{ AVE } & \multicolumn{7}{|c|}{ Discriminant validity } \\
\cline { 8 - 12 } & $\boldsymbol{C R}$ & $\boldsymbol{\alpha}$ & & $\mathbf{1}$ & $\mathbf{2}$ & $\mathbf{3}$ & $\mathbf{4}$ & $\mathbf{5}$ & $\mathbf{6}$ & $\mathbf{7}$ \\
\hline 1 & 0.92 & 0.87 & 0.79 & 0.89 & & & & & & \\
\hline 2 & 0.91 & 0.86 & 0.71 & 0.75 & 0.84 & & & & & \\
\hline 3 & 0.87 & 0.81 & 0.63 & 0.68 & 0.71 & 0.79 & & & & \\
\hline 4 & 0.88 & 0.81 & 0.64 & 0.62 & 0.75 & 0.67 & 0.80 & & & \\
\hline 5 & 0.88 & 0.79 & 0.70 & 0.65 & 0.73 & 0.72 & 0.66 & 0.84 & & \\
\hline 6 & 0.89 & 0.84 & 0.68 & 0.67 & 0.68 & 0.74 & 0.76 & 0.73 & 0.82 & \\
\hline 7 & 0.87 & 0.77 & 0.69 & 0.56 & 0.54 & 0.52 & 0.57 & 0.54 & 0.63 & 0.83 \\
\hline
\end{tabular}

Note. 1 = acceptance; 2 = attitude; $3=$ connected learning; 4 = perceived ease of use; $5=$ perceived playfulness; $6=$ perceived usefulness; and $7=$ Subjective norm.

In Table 3 above, the coefficient of CR ranged from 0.87 to 0.92 while AVE was between 0.63 and 0.79 . Such findings showed that all the values were above the recommended CR threshold of 0.60 and AVE threshold of 0.50 , indicating the acceptable convergent reliability of all factors. Furthermore, the square root AVE of each factor was observed to be higher than its correlation with any other factors in the current study. The finding indicates that the discriminant validity of the constructs was satisfactory. Also, all alpha values were observed as greater than 0.70 , indicating that the reliability of the constructs was also satisfactory. Although the statistical calculation of the six constructs of the unified theory of acceptance and use of technology (UTAUT) section and connected learning environment has suggested validity of the instruments, several conditions could be found to contribute to the UTAUT and connected learning e.g. hardware reliability, internet speed and reliability (see Papadakis, 
Vaiopoulou, Kalogiannakis, and Stamovlasis [6]). While the current study only involved some cohorts of students from one vocational higher education, the findings cannot present the views of the Indonesian higher education students in general.

To address Research Question 1, a quantitative analysis using the Structural Equation Model analysis was performed to evaluate students' acceptance of the use of smartphones and social media to promote m-learning.

Table 4. Path analysis and t-value

\begin{tabular}{|l|c|c|}
\hline & Path coefficients & t-value \\
\hline $\begin{array}{l}\text { Attitude towards social media } \\
\text { Acceptance of using social media for m-learning }\end{array}$ & 0.54 & $7.93^{*}$ \\
\hline $\begin{array}{l}\text { Connected learning } \\
\text { Acceptance of using social media for m-learning }\end{array}$ & 0.29 & $3.98^{*}$ \\
\hline $\begin{array}{l}\text { Attitude towards social media } \\
\text { Attitude towards social media }\end{array}$ & 0.25 & $2.62^{*}$ \\
\hline $\begin{array}{l}\text { Perceived playfulness } \\
\text { Attitude towards social media }\end{array}$ & 0.40 & $4.51^{*}$ \\
\hline $\begin{array}{l}\text { Perceived usefulness } \\
\text { Attitude towards social media }\end{array}$ & 0.29 & $3.81^{*}$ \\
\hline $\begin{array}{l}\text { Subjective norm } \\
\text { Attitude towards social media }\end{array}$ & -0.06 & 0.62 \\
\hline
\end{tabular}

Note. $* \mathrm{p}<.01$

As shown in Table 4, students' attitude towards social media $(\beta=0.54, \mathrm{p}<.01)$ and their feeling of connectedness to learning $(\beta=0.29, \mathrm{p}<.01)$ significantly influenced their acceptance of using social media for m-learning. Moreover, students' attitude towards social media for m-learning was statistically affected by their connectedness to learning $(\beta=0.25, \mathrm{p}<.01)$, perceived ease of use $(\beta=0.40, \mathrm{p}<.01)$, and perceived playfulness $(\beta=0.29, \mathrm{p}<.01)$. The dimension of students' perceived usefulness $(\beta=-0.06, p>.01)$ and their subjective norm $(\beta=0.07, p>.01)$ were not significantly associated to their attitude towards social media for m-learning.

\subsection{Findings of the qualitative data analysis}

Research Question 2 attempted to evaluate the extent to which m-learning with smartphones and social media facilitates students' learning motivation, interaction and learning performance. Findings from students' reflection showed that students utilised some smartphone applications to facilitate their mobile learning, such as a social media application (e.g. WhatsApp), word processing application (e.g. Memo) and some multimedia design application (e.g. PiscArt, Photoshop, and Lightroom). Also, the analysis of students' reflection has suggested that students' use of mobile learning using smartphones increased their learning motivation. Students wrote in their reflection that using a smartphone for mobile learning was easy and time-efficient. Students were observed to study and work on their project anywhere and anytime. Besides, the incorporation of the smartphone for mobile learning had eased students' communication and interaction which thus developed their motivation to learn. 
Respondent Rudi acknowledged such ease of communication and interaction with his teachers and friends. Similarly, Mirna said:

"(The)smartphone helps me to interact with my teacher, who may not be around in the campus. I can contact him and ask for feedback regarding my assignment offcampus."

In addition to learning motivation, the analysis of students' reflection found that students used smartphone applications that promoted mutual social interaction and thus improved their learning activities. Students were observed to search some learning resources, to share information and materials about the learning, and smartphone use enabled discussion, peer-assessment and feedback. Mirna, for example, used her smartphone to search for other references related to her book design project from the internet after receiving feedback from her teacher. Anton also mentioned his use of his smartphone for finding learning resources and showed two captures as below:



Fig. 1. Screen captures of Anton's use of his smartphone for finding learning resources

Another student, Rudi, mentioned that he used a word processing application installed on his smartphone to write and edit a draft of his project. He also said he used the device to send his early draft to his teachers and peers to obtain feedback. Anton also mentioned that the smartphone had eased him into the habit of sending and receiving learning materials. Also, the finding of the current study indicated the advanced use of smartphones for small-scale design and editing purposes. One 
student, Andy, said that he used mobile design applications such as PiscArt, Photoshop and Lightroom to help him work with some small-scale designs.

Despite the benefits that the smartphone and social media had offered to the students, some critical issues were highlighted in such a practice, including limited access to the internet, limited features offered on the smartphone and limited space for interaction and explanation. One of the students, Rudi, said that his limited internet access at home and on campus had constrained his opportunity to communicate and interact. Some students also mentioned that they were not able to install some sophisticated application for their project due to limited storage on the phones. Also, students felt that the teacher's explanation provided via WhatsApp was hard to comprehend due to the limited space given in the apps. Accordingly, students were observed to be more comfortable in face-to-face interaction with their teachers than using a smartphone. Mirna confirmed that her teachers' digital explanations were frequently limited, which were difficult for her to understand. She mentioned her preference to meet and consult on her work with her teacher directly rather than using a smartphone.

\section{Discussion}

The current study aimed to evaluate students' acceptance of using social media and the extent to which the smartphone and social media might promote m-learning situated in a vocational higher education setting. Findings from the quantitative data analysis suggest that students' acceptance of incorporating social media to promote their m-learning was statistically influenced by their attitude and connectedness to the application. Specifically, the students' connectedness, perceived ease of use and perceived playfulness of using social media for m-learning affected their attitude. This finding corresponds with the earlier study by Dhume, Pattanshetti, Kamble, and Prasad [48] and Teo, Lee, Chai, and Wong [49], suggesting that students' acceptance of technology use is associated with students' attitude and intention to use social media for learning. In other words, students' attitude plays a key role in understanding their acceptance of using technology for educational purposes.

One of the interesting findings suggests that the acceptance of social media for $\mathrm{m}$ learning is particularly associated with students' connectedness to learning rather than perceived usefulness of such an application which confirms the earlier study by Lai, Wang, and Lei [50]. Lai, Wang and Lei found that the variable of perceived usefulness of technology played little role in predicting students' actual use of technology for learning. The role of teacher authority to promote the use of smartphones and social media might be the driver for students' high level of connectedness to the smartphone and social media. In the reflections, students acknowledged that their teachers' instruction drove their use of smartphone applications. One of the students mentioned that she was not allowed to submit her work unless she obtained feedback and approval from her teacher, and the feedback and approval were mainly given through WhatsApp. These findings were also reported in some earlier study. A study by Solihat and Mulyono [1] has suggested the incorporation of smartphones in class- 
room instruction and online testing. Sung and Mayer [51] suggest that smartphone technology is a convenient tool that improves students' motivation and engagement in their learning. A study by Alzubi and Singh [52] that evaluated English as a foreign language (EFL) undergraduate students' smartphone features and applications to advance their reading skills also found that students were assured, and profoundly motivated through self-regulating their mobile learning. Moreover, a study by Li et al. (2018) revealed that the incorporation of the smartphone to facilitate mobile learning helped develop students' motivation to learn. However, they still encountered inadequate self-efficacy and were noticed to only feel lightly satisfied with the application.

It is important to argue that students' connectedness to the learning through the incorporation of smartphones and social media was mainly due to their strong motivation to participate actively in learning, to stay connected with information during the learning activity and to develop the communication between students and their teachers and between students themselves. As shown in the reflection, the smartphone had motivated the students to share information and materials about the learning and enabled peer-assessment and feedback. These activities were potential for further collaborative activities amongst the students [26]. So [54] argues that this would facilitate students' learning and improve their learning involvement. Particularly, Yanti and Mulyono [55] suggest that smartphone may facilitate project-based learning by optimising the video and editing features available in the phone.

Besides, the communication and interaction that occurred between the students and between students and their teachers have shown the primary benefits of mobile learning with a smartphone. Such findings were in line with what Alrasheedi, Capretz, and Raza [56] has suggested that mobile learning with a smartphone enables students to monitor their learning activities by themselves at any time and in any place where they are willing to learn. Moreover, Hamidi and Chavoshi [57] believe that such communication and interaction would improve over time as they could ask each other without the limitation of place and time. Students were enabled to review and evaluate a task or simply ask for feedback from their teachers or peers. Such benefits, accordingly, would benefit students' learning activities. More importantly, the communication and interaction created in the mobile learning environment with smartphone use as shown in the findings of the current study is believed to support students' learning, promote students' self-paced learning and enable social interaction between the teacher, students, and their peers [21]. Such conditions have indicated the incorporation of smartphone in students' learning has created an authentic learning environment [4], [55], [58] and accordingly may improve their learning performances. Although, there is unclear from the findings if students' active communication as well as interactions were enabled from teachers' quality instructions.

\section{Conclusion}

To conclude, mobile learning with the smartphone brings new knowledge to the university students and makes mobile learning possible. Findings of the current study have revealed that students' attitude and connectedness to the smartphone and social 
media play prominent roles in determining their acceptance of smartphones and social media for m-learning. Specifically, the students' connectedness, perceived ease of use and perceived playfulness of using social media for m-learning affected their attitude. Findings also showed that students' mobile learning using a smartphone helped develop their learning motivation, facilitated learning activities and enabled mutual interaction between the students, and between teachers and students. Students also benefited from the use of smartphones in that they could share information and materials about the learning, enabled peer-assessment and feedback. These activities were potential for further collaborative activities amongst the students [26]. So [54] argues that this would facilitate students' learning and improve their learning involvement.

Although students were shown to use some design applications on the phone, their activity was still limited to small-scale design and editing. Two critical issues identified were the limited features offered in the smartphone and limited space for interaction and explanation. Students' preference for teacher-student face-to-face interaction emphasised the prominent role of teachers' presence in the classroom. It is, therefore, argued that further instructional practices should consider these critical issues and prepare a more flexible design that allows more interaction as well as discussion between teachers and students.

It is also important to acknowledge the limitations of the current study. First, the current study was contextualised in a state vocational higher education setting in Indonesia and the selection of the sample followed a non-probability sampling method. Therefore, the findings of the study cannot be generalised to capture the view of all vocational higher education students. Second, using the qualitative data which were gathered using written reflection had constrained the researchers to explore more information from the participants. Further research on similar topics should, therefore, address these limitations.

\section{$7 \quad$ References}

[1] N. Solihati and H. Mulyono, 'Designing and Evaluating the Use of Smartphones to Facilitate Online Testing in Second-Language Teacher Education (SLTE): An AutoEthnographic Study', Int. J. Emerg. Technol. Learn., vol. 13, no. 1, pp. 124-137, 2018. https://doi.org/10.3991/ijet.v13i01.7683

[2] Y. J. Joo, N. Kim, and N. H. Kim, 'Factors predicting online university students' use of a mobile learning management system (m-LMS)', Educ. Technol. Res. Dev., vol. 64, no. 4, pp. 611-630, 2016. https://doi.org/10.1007/s11423-016-9436-7

[3] A. Hikmat and H. Mulyono, 'Smartphone use and multitasking behaviour in a teacher education program (TEP)', Int. J. Interact. Mob. Technol., vol. 12, no. 2, pp. 4-14, 2018. https ://doi.org/10.3991/ijim.v12i2.7345

[4] H. Mulyono and G. Suryoputro, 'The use of social media platform to promote authentic learning environment in hgiher education setting', Sci. Educ. Today, vol. 10, no. 2, pp. 105-123, 2020. https://doi.org/10.15293/2658-6762.2002.07

[5] S. N. Şad and Ö. Göktaş, 'Preservice teachers' perceptions about using mobile phones and laptops in education as mobile learning tools', Br. J. Educ. Technol., vol. 45, no. 4, pp. 606-618, 2014. https://doi.org/10.1111/bjet.12064 
[6] S. Papadakis, J. Vaiopoulou, M. Kalogiannakis, and D. Stamovlasis, 'Developing and exploring an evaluation tool for educational apps (ETEA) targeting kindergarten children', Sustainability, vol. 12, no. 10, p. 4201, 2020. https://doi.org/10.3390/su12104201

[7] J. Gikas and M. M. Grant, 'Mobile computing devices in higher education: Student perspectives on learning with cellphones, smartphones \& social media', Internet High. Educ., vol. 19, pp. 18-26, 2013. https://doi.org/10.1016/j.iheduc.2013.06.002

[8] J. E. Rodriguez, 'Social media use in higher education: Key areas to consider for educators', MERLOT J. Online Learn. Teach., vol. 7, no. 4, pp. 539-550, 2011.

[9] R. Chugh and U. Ruhi, 'Social media in higher education: A literature review of Facebook', Educ. Inf. Technol., vol. 23, no. 2, pp. 605-616, 2018. https://doi.org/10.1007/s10 639-017-9621-2

[10] C. Irwin, L. Ball, B. Desbrow, and M. Leveritt, 'Students' perceptions of using Facebook as an interactive learning resource at university', Australas. J. Educ. Technol., vol. 28, no. 7, 2012. https://doi.org/10.14742/ajet.798

[11] M. Makoe, 'Exploring the use of MXit: a cell - phone social network to facilitate learning in distance education', Open Learn. J. Open, Distance e-Learning, vol. 25, no. 3, pp. 251257, 2010. https://doi.org/10.1080/02680513.2010.512099

[12] V. Bozalek et al., 'The use of emerging technologies for authentic learning: AS outh A frican study in higher education', Br. J. Educ. Technol., vol. 44, no. 4, pp. 629-638, 2013. https://doi.org/10.1111/bjet.12046

[13] A. E. E. Sobaih, M. A. Moustafa, P. Ghandforoush, and M. Khan, 'To use or not to use? Social media in higher education in developing countries', Comput. Human Behav., vol. 58, pp. 296-305, 2016. https://doi.org/10.1016/j.chb.2016.01.002

[14] E. Dahlstrom, 'ECAR study of undergraduate students and information technology', 2012.

[15] S. Papadakis, M. Kalogiannakis, E. Sifaki, and N. Vidakis, 'Evaluating Moodle use via Smart Mobile Phones. A case study in a Greek University', EAI Endorsed Trans. Creat. Technol., vol. 5, no. 16, 2018. https://doi.org/10.4108/eai.10-4-2018.156382

[16] M. Al-Ismail, M. Yamin, Y. Liu, and T. Gedeon, 'Learners characteristics of m-learning preferences', Int. j. inf. tecnol., pp. 1-13, 2019.

[17] L. Pedro, C. Barbosa, and C. Santos, 'A critical review of mobile learning integration in formal educational contexts', Int. J. Educ. Technol. High. Educ., vol. 15, no. 10, pp. 1-15, 2018. https://doi.org/10.1186/s41239-018-0091-4

[18] S. Papadakis, 'Evaluating pre-service teachers' acceptance of mobile devices with regards to their age and gender: a case study in Greece.', Int. J. Mob. Learn. Organ., vol. 12, no. 4, pp. 336-352, 2018. https://doi.org/10.1504/ijmlo.2018.10013372

[19] W. Chang, Y. Liu, and T. Huang, 'Perceptions of learning effectiveness in m-learning: Scale development and student awareness', J. Comput. Assist. Learn., pp. 1-12, 2017.

[20] P. S. Seow and S. P. Wong, 'Using a mobile gaming app to enhance accounting education', J. Educ. Bus., vol. 91, no. 8, pp. 434-439, 2016. https://doi.org/10.1080/08832323. $\underline{2016.1256264}$

[21] K. C. Li, L. Y. K. Lee, S. L. Wong, I. S. Y. Yau, and B. T. M. Wong, 'Effects of mobile apps for nursing students: learning motivation, social interaction and study performance', Open Learn., vol. 33, no. 2, pp. 99-114, 2018. https://doi.org/10.1080/02680513.2018.145 $\underline{4832}$

[22] R. Cheung, 'Predicting user intentions for mobile learning in a project-based environment', " Int. J. Electron. Commer. Stud., vol. 4, no. 2, pp. 263-280, 2014.

[23] J. Cheon, S. Lee, S. M. Crooks, and J. Song, 'An investigation of mobile learning readiness in higher education based on the theory of planned behavior', Comput. Educ., vol. 59, no. 3, pp. 1054-1064, 2012. https://doi.org/10.1016/j.compedu.2012.04.015 
[24] K. Mac Callum and L. Jeffrey, 'The influence of students' ICT skills and their adoption of mobile learning', Australas. J. Educ. Technol., vol. 29, no. 3, 2013.

[25] G. Siemens and M. Weller, 'Higher education and the promises and perils of social network', Rev. Univ. y Soc. del Conoc., vol. 8, no. 1, pp. 164-170, 2011.

[26] M. K. Kabilan, N. Ahmad, and M. J. Z. Abidin, 'Facebook: An online environment for learning of English in institutions of higher education?', Internet High. Educ., vol. 13, no. 4, pp. 179-187, 2010. https://doi.org/10.1016/j.iheduc.2010.07.003

[27] A. Susilo, 'Use of Facebook for academic network learning in Universitas TerbukaIndonesia', Asian Assoc. Open Univ. J., 2008. https://doi.org/10.1108/aaouj-03-02-2008$\underline{\mathrm{b} 003}$

[28] H. Salikin and S. Z. Bin Tahir, 'The social media-based approach in teaching writing at Jember University, Indonesia', Int. J. English Linguist., vol. 7, no. 3, p. 46, 2017. https:// doi.org/10.5539/ijel.v7n3p46

[29] A. La Hanisi, R. Risdiany, Y. Dwi Utami, and D. Sulisworo, 'The use of WhatsApp in collaborative learning to improve English teaching and learning process', Int. J. Res. Stud. Educ. Technol., vol. 7, no. 1, pp. 29-35, 2018. https://doi.org/10.5861/ijrset.2018.3004

[30] U. Rahaded, E. Puspitasari, and D. Hidayati, 'The Impact of Whatsapp Toward UAD Undergraduate Students' Behavior In Learning Process’, Int. J. Educ. Manag. Innov., vol. 1, no. 1, pp. 55-68, 2020. https://doi.org/10.12928/ijemi.v1i1.1515

[31] J. W. Creswell, Educational research: Planning, conducting, and evaluating quantitative and qualitative research, 4th ed. Pearson, 2012.

[32] L. Cohen, L. Manion, K. Morrison, and R. Bell, Research methods in education, 8th ed. London: Routledge, 2018.

[33] C. M. Ringle, S. Wende, and J.-M. Becker, 'SmartPLS 3'. Boenningstedt: SmartPLS

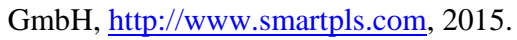

[34] S. K. Ningsih, S. Narahara, and H. Mulyono, 'An exploration of factors contributing to students' unwillingness to communicate in a foreign language across Indonesian secondary schools.', Int. J. Instr., vol. 11, no. 4, pp. 811-824, 2018. https://doi.org/10.12973/iji.2018. $\underline{11451 \mathrm{a}}$

[35] S. Zulaiha and H. Mulyono, 'Exploring junior high school EFL teachers' training needs of assessment literacy’, Cogent Educ., vol. 7, no. 1, p. 1772943, Jan. 2020. https://doi.org/10. 1080/2331186x.2020.1772943

[36] A. Lawson-Body, L. Willoughby, L. Lawson-Body, and E. M. Tamandja, 'Students' acceptance of E-books: An application of UTAUT', J. Comput. Inf. Syst., pp. 1-12, 2018. https://doi.org/10.1080/08874417.2018.1463577

[37] H. H. Yang, L. Feng, and J. MacLeod, 'Understanding college students' acceptance of cloud classrooms in flipped instruction: integrating UTAUT and connected classroom climate', J. Educ. Comput. Res., vol. 56, no. 8, pp. 1258-1276, 2019. https://doi.org/10.1177/ $\underline{0735633117746084}$

[38] V. Venkatesh, M. G. Morris, G. B. Davis, and F. D. Davis, 'User acceptance of information technology: Toward a unified view', MIS Q., pp. 425-478, 2003. https://doi.org/ $10.2307 / 30036540$

[39] D. Z. Dumpit and C. J. Fernandez, 'Analysis of the use of social media in Higher Education Institutions (HEIs) using the Technology Acceptance Model', Int. J. Educ. Technol. High. Educ., vol. 14, no. 1, p. 5, 2017. https://doi.org/10.1186/s41239-017-0045-2

[40] K. K. Dwyer, S. G. Bingham, R. E. Carlson, M. Prisbell, A. M. Cruz, and D. A. Fus, 'Communication and connectedness in the classroom: Development of the connected classroom climate inventory', Commun. Res. Reports, vol. 21, no. 3, pp. 264-272, 2004. https://doi.org/10.1080/08824090409359988 
[41] D. Coulson and M. Harvey, 'Scaffolding student reflection for experience-based learning: A framework', Teach. High. Educ., vol. 18, no. 4, pp. 401-413, 2013. https://doi.org/10.10 $\underline{80 / 13562517.2012 .752726}$

[42] N. Zacharias, 'Prompting second language writers for productive reflection using narrative questioning prompt', Indones. JELT, vol. 14, no. 2, pp. 115-133, 2019. https://doi.org/10.2 5170/ijelt.v14i2.1441

[43] S. Quinton and T. Smallbone, 'Feeding forward: using feedback to promote student reflection and learning-a teaching model', Innov. Educ. Teach. Int., vol. 47, no. 1, pp. 125-135, 2010. https://doi.org/10.1080/14703290903525911

[44] T. S. C. Farrell, Reflective language teaching: From research to practice. London, New York: Continuum, 2007.

[45] N. Solihati and H. Mulyono, 'A Hybrid classroom instruction in second language teacher education (SLTE): A critical reflection of teacher educators', Int. J. Emerg. Technol. Learn., vol. 12, no. 5, pp. 169-180, 2017. https://doi.org/10.3991/ijet.v12i05.6989

[46] C. R. Rayford, 'Reflective practice: The teacher in the mirror', Graduate College University of Nevada, Las Vegas, 2010.

[47] J. F. Hair Jr, G. T. M. Hult, C. Ringle, and M. Sarstedt, A primer on partial least squares structural equation modelling (PLS-SEM). Sage publications, 2017. https://doi.org/10.392 6/oss.37

[48] S. M. Dhume, M. Y. Pattanshetti, S. S. Kamble, and T. Prasad, 'Adoption of social media by business education students: Application of Technology Acceptance Model (TAM)', in 2012 IEEE International Conference on Technology Enhanced Education (ICTEE), 2012, pp. 1-10. https://doi.org/10.1109/ictee.2012.6208609

[49] T. Teo, C. B. Lee, C. S. Chai, and S. L. Wong, 'Assessing the intention to use technology among pre-service teachers in Singapore and Malaysia: A multigroup invariance analysis of the Technology Acceptance Model (TAM)', Comput. Educ., vol. 53, no. 3, pp. 10001009, 2009. https://doi.org/10.1016/j.compedu.2009.05.017

[50] C. Lai, Q. Wang, and J. Lei, 'What factors predict undergraduate students' use of technology for learning? A case from Hong Kong', Comput. Educ., vol. 59, no. 2, pp. 569-579, 2012. https://doi.org/10.1016/j.compedu.2012.03.006

[51] E. Sung and R. Mayer, 'Online multimedia learning with mobile devices and desktop computers: An experimental test of Clark's methods-not-media hypothesis', Comput. Human Behav., vol. 29, pp. 639-647, 2013. https://doi.org/10.1016/j.chb.2012.10.022

[52] A. Alzubi and M. Singh, 'The impact of social strategies through smartphones on the Saudi learners' socio-cultural autonomy in EFL reading context', Int. Electron. J. Elem. Educ., vol. 11, no. 1, pp. 31-40, 2018. https://doi.org/10.26822/iejee.2018143958

[53] I. S. H. Wai, S. S. Y. Ng, D. K. W. Chiu, K. K. W. Ho, and P. Lo, 'Exploring undergraduate students' usage pattern of mobile apps for education', J. Librariansh. Inf. Sci., vol. 50, no. 1, pp. 34-47, 2018. https://doi.org/10.1177/0961000616662699

[54] S. So, 'Mobile instant messaging support for teaching and learning in higher education', Internet High. Educ., vol. 31, pp. 32-42, 2016. https://doi.org/10.1016/j.iheduc.2016.06. $\underline{001}$

[55] P. Yanti and H. Mulyono, 'Incorporating a Smartphone Video in a Theatrical Activity to Promote an Authentic Language Learning Environment in a Lower Secondary School Classroom', 2020. https://doi.org/10.3991/ijim.v14i01.11499

[56] M. Alrasheedi, L. F. Capretz, and A. Raza, 'A systematic review of the critical factors for success of mobile learning in higher education (university students' perspective)', J. Educ. Comput. Res., vol. 52, no. 2, pp. 257-276, 2015. https://doi.org/10.1177/07356331155719 $\underline{28}$ 
[57] H. Hamidi and A. Chavoshi, 'Analysis of the essential factors for the adoption of mobile learning in higher education: A case study of students of the University of Technology', Telemat. Informatics, vol. 35, no. 4, pp. 1053-1070, 2018. https://doi.org/10.1016/j.tele.20 17.09 .016

[58] A. Herrington and J. Herrington, 'What is an authentic learning environment?', in Authentic learning environments in higher education, A. Herrington and J. Herrington, Eds. Information Science Publishing, 2008, pp. 68-77. https://doi.org/10.4018/978-1-59140-594$\underline{8 . \operatorname{ch} 001}$

\section{Authors}

Purnomo Ananto is an associate professor and currently the director of State Polytechnic of Kreatif Media, Jakarta, Indonesia. His research interests include education administration and management and the use of technology for teaching and learning in vocational higher education.

Sri Kusuma Ningsih is a lecturer at University of Muhammdiyah Prof. DR. HAMKA, Jakarta, Indonesia. She obtained her Master's at the same university and is currently pursuing her doctoral study at Universitas Pendidikan Indonesia, Bandung, Indonesia. Her research mainly focuses on the use of technology for teachers' professional development. sri_kusuma@uhamka.ac.id

Article submitted 2020-02-29. Resubmitted 2020-08-18. Final acceptance 2020-08-18. Final version published as submitted by the authors. 